\title{
Electron transport system (ETS) activity as a measure of benthic macrofaunal metabolism*
}

\author{
Leon M. Cammen, Susannah Corwin, John P. Christensen \\ Bigelow Laboratory for Ocean Sciences, West Boothbay Harbor, Maine 04575, USA
}

\begin{abstract}
The accurate determination of respiration rates is critical to any study of energy flow through marine ecosystems, and in energy budgets of individual marine invertebrates, respiration generally accounts for the major portion of the organic matter ingested. However, there are limitations to current methods for measuring respiration in macrobenthic invertebrates as they are generally applied: measurements are made in the laboratory, not in the field; they are usually carried out in clean sediment or in no sediment at all; and the animals typically are starved during the experiments. This study reports the first application of electron transport system (ETS) activity to estimate in situ rates of oxygen utilization in macrobenthic invertebrates. Measurements of ETS activity and oxygen uptake (R) were made on 2 intertidal species, the polychaete Nereis virens and the amphipodCorophium volutator, under natural conditions and during starvation. ETS activity was related to body size in both species in a manner typical for a metabolic function (ETS $=\alpha W^{\beta}$ ). R: ETS ratios were 0.09 for $N$. virens and 0.42 for $C$. volutator (cf, a literature value of 0.49 for zooplankton). The lower ratio for the former may result from a more sedentary life style or the importance of anaerobic pathways to their overall energetics. The general trend of the starvation experiments for both species was that oxygen uptake declined over 10 to $12 \mathrm{~d}$, but ETS activity remained relatively constant. C. volutator ETS activity was lower in early spring and consistently higher from early summer through fall while $N$. virens had its highest activity in the early spring and a lower but consistent level of activity in summer and fall; the changes may have been related to the abundance of food resources or to reproductive activity. ETS activity is potentially useful as an estimator of long-term variability in metabolic activity of marine macrofauna.
\end{abstract}

\section{INTRODUCTION}

The accurate determination of respiration rates is critical to any study of energy flow through marine ecosystems, since respiration and either sedimentation (in pelagic systems) or burial (in benthic systems) generally represent the ultimate sinks of the organic matter produced in the system. In energy budgets of individual marine invertebrates, respiration usually accounts for the major portion of the organic matter ingested (Conover 1978, Parsons et al. 1984, Cammen 1987).

Several different methods have been employed to estimate the amount of carbon or the energy equivalent respired by marine invertebrates. These include: (1) measuring oxygen uptake and applying a conversion factor (the respiratory quotient) to estimate the release

\footnotetext{
- Bigelow Laboratory for Ocean Sciences Contribution No. 90008
}

of carbon dioxide or energy (e.g. Hargrave 1971, Cammen 1980); (2) uniformly labelling the animals with ${ }^{14} \mathrm{C}$ and then measuring the release of ${ }^{14} \mathrm{CO}_{2}$ into the water (e.g. Kofoed 1975, Cammen 1985); (3) using calorimetry to measure the metabolic heat produced by the animals directly (e.g. Pamatmat 1983, Pamatmat \& Findlay 1983); and (4) measuring weight loss over time in starving animals and extrapolating back to the initial loss rate (this loss rate also includes the metabolic release of dissolved and particulate organic carbon; Cammen 1985).

However, there are similar flaws in all of these methods as they are generally applied when estimating respiration rates of benthic infauna:

(1) They are carried out in the laboratory, not in the field. The level of activity of an organism is perhaps the most obvious factor affecting the metabolic rate, yet at the same time it is one of the most difficult to duplicate adequately in the laboratory. Any number of stimuli (or lack thereof) can cause problems; stimuli which might 
not be duplicated in the laboratory could include interactions with other individuals in the community, tidal inundation, current regime, water quality (including POC, DOC and oxygen concentrations), light level and quality, and many others. Thus, the level of activity during a laboratory measurement of oxygen consumption, while reproducible and useful for relative interspecies comparisons, may be quite different from that typical for a given species in the field. For example, a diurnal rhythm exists in some polychaetes with respiration being higher during the day than at night (Mangum \& Miyamoto 1970, Sander 1973), yet respiration rates are commonly measured in the dark to reduce the effect of external disturbances. As a second example, Nichols (1975) estimated that oxygen consumption of the tube-dwelling polychaete Pectinaria californiensis would have been over-estimated by 2 times if measurements had been made in air-saturated seawater due to the relatively low oxygen concentration in the tubes. More generally, growth rates of polychaetes are invariably higher in the laboratory than in the field, presumably due to the failure to duplicate in situ conditions (Cammen 1987).

(2) The measurements are carried out in clean sediment or in no sediment at all. In many natural sediments, microbial respiration would otherwise overwhelm the respiration of the target organisms, particularly if they are small, yet the lack of a natural sediment environment must stress the organisms. In addition, many species normally ventilate while in burrows but not while free in the water and oxygen consumption while actively ventilating can be much higher than when resting. For example, overall rates of oxygen consumption for 4 polychaete species, including periods of ventilation, were about 4 times the resting consumption (Mangum \& Sassaman 1969, Kristensen 1981). To an animal that has spent its entire adult life in the sediment, removal from that sediment must represent an extremely unnatural situation with an unpredictable effect on the respiration rate (Vernberg et al. 1977. Pamatmat 1982).

(3) The animals are usually starved during the measurements. Whether an organism is well-fed or starving can have a profound effect on its metabolic rate (Vernberg 1959, Wallace 1973, Lane \& Lawrence 1979, Newell 1979, Cuzon et al. 1980, Famme \& Kofoed 1982), but it is difficult to measure oxygen uptake by an animal feeding at a normal rate on its natural food. For example, actively feeding Capitella capitata (Polychaeta) had metabolic rates 6 times higher than nonfeeding individuals (Pamatamat \& Findlay 1983). Part of the increase is probably due to the increased activity associated with feeding and part to the increased metabolic activity associated with digestive and assimilatory processes (Bayne et al. 1976). Since metabolic activity begins to decline soon after the onset of starvation (Pamatamat \& Findlay 1983), the effect may be present even when the animals have only recently been removed from their environments.

Of course, some of these weaknesses in experimental design can be overcome, but unfortunately there are some problems inherent to laboratory measurements that cannot be corrected. For example, even though the animals can be fed, questions as to the optimal experimental design will remain: What is the appropriate food, how much of it should be given and how often, and how can the animal be made to duplicate the amount of effort needed to obtain it in the field? The failure of laboratory growth rates for polychaetes to duplicate field growth rates despite attempts to provide natural sediment, light, and water exchange, simply emphasizes the problem (Cammen 1987).

Where, then, does this leave us in our attempt to understand the respiratory energetics of benthic infauna? While we have collected abundant data on benthic infaunal respiration that are useful for comparative physiology, the data are probably less useful in studies of benthic energetics. The ideal method would avoid laboratory artifacts by measuring respiration rates in situ without altering the animals' environments or feeding regimes. Virtually the only existing method for direct measurement of oxygen consumption in the field is the use of microelectrodes; however, these measurements are difficult and time-consuming and thus must be limited in number and scope. Access to the sediment is required in order to use micromanipulators and this tends to restrict the measurements to intertidal and shallow water areas; in addition, measurements are possible only for relatively immobile species while resting in their burrows and that limitation excludes a large fraction of the macrobenthos. We describe here the application of a more general method, namely the measurement of electron transport system activity, to estimate in situ rates of oxygen utilization in macrobenthic invertebrates

\section{DESCRIPTION OF THE ELECTRON TRANSPORT SYSTEM}

All organisms that respire do so through a respiratory chain of enzymes called the electron transport system (ETS). The ETS passes electrons along a series of intermediary dehydrogenases and cytochromes to an electron acceptor such as $\mathrm{O}_{2}, \mathrm{NO}_{3}$, or $\mathrm{SO}_{4}$; it enables organisms to carry out oxidative phosphorylation and provides the energy used to generate ATP.

Electron transport systems in marine organisms have been reviewed by Vosjan (1982) and Packard (1985a, b). ETS activity has been measured extensively in bac- 
teria, protozoans, phytoplankton, zooplankton, and fish, as well as in seawater and sediments. A recent study has applied the technique to meiobenthic nematodes and copepods (Houri-Davignon et al. 1989). However, prior to this project, there had been only 2 studies dealing with marine macrofauna and those considered only tissue samples, not whole organisms (Hand \& Somero 1983, Zaba 1983); we are not aware of any attempts to use measurements of ETS activity in whole animals to estimate respiration rates for benthic macrofauna.

The ETS assay actually measures the potential respiration that could be supported by the existing enzymatic 'machinery', not the actual rate of respiration. In order for the ETS method to be useful in studies of ecological energetics, it is necessary to use a conversion factor to relate the potential to the actual respiration rate. Initial expectations were that a cell would respire at about half its maximum capacity under steadystate conditions (Packard 1985b). These expectations were based on the assumption that ETS activity would follow Michaelis-Menten kinetics with the concentration of the respiratory regulator being maintained near $\mathrm{K}_{\mathrm{m}}$; this would allow a cell to control its respiration rate efficiently by making only small changes in the concentration of the regulator. As laboratory measurements of the ratio between respiration and ETS activity (R:ETS) have accumulated, it has become clear that the ratios can vary significantly from 0.5. Packard (1985b) summarized R:ETS ratios for various organisms from the literature and the means were 0.17 for eukaryotic microalgae, 0.49 for zooplankton (one value of $0.21,5$ values between 0.50 and 0.68 ), and 1.10 for bacteria; all values have been converted to be equivalent to the ETS method of Owens \& King (1975) using factors from Christensen \& Packard (1979). The values for zooplankton are the only data we have from metazoans measured under natural conditions and analyzed as intact organisms, not tissue extracts, and that mean was indistinguishable from the original suggestion of 0.5 .

The objective of this study was to evaluate the ETS technique for use with benthic infauna in order to determine if it has the potential to provide ecologically meaningful estimates of in situ respiration rates. ETS activities and R:ETS ratios were measured for 2 intertidal macrofaunal species under simulated natural conditions (in the presence of sediment) to establish natural levels of activity and the response to long-term (seasonal) environmental variability, and under presumably stressful conditions (in the absence of sediment) to investigate the time-scale of the response. Based on these limited data, it appears that the technique will be useful for estimating in situ metabolic rates for benthic invertebrates.

\section{METHODS}

The experimental organisms for this study were the polychaete Nereis virens and the amphipod Corophium volutator All animals were collected from an intertidal mudflat located near the laboratory.

Determination of ETS activity. ETS activity was determined following Owens \& King (1975). Briefly, the technique was to: (1) obtain a cell-free homogenate of the animal; (2) incubate the homogenate with NADH to saturate the mitochondrial ETS, NADPH to saturate the microsomal ETS, and an artificial electron acceptor [1 - (4 - iodopheny] ) - 3 - (4 -nitrophenyl) - 5 - phenylte trazolium chloride (INT)] to register the electron transmission rate; and (3) calculate the potential oxygen consumption rate from the molar production rate of INTformazan which was determined spectrophotometrically. Animals were preserved in liquid nitrogen until their analysis in order to maintain the ETS activity (Ahmed et al. 1976). The homogenates were obtained by grinding the animals in a tissue homogenizer, centrifuging, then subsampling and diluting with grinding buffer; all these manipulations were carried out with the samples held on ice. ETS activity was calculated in $\mu \mathrm{g}$-at. $\mathrm{O}_{2} \mathrm{~h}^{-1}$ based on the equivalence of the reduction of 2 mol INT-formazan to the consumption of $1 \mathrm{~mol}$ oxygen. All assays were incubated at $10^{\circ} \mathrm{C}$ for $20 \mathrm{~min}$ and were terminated by the addition of a quench solution made up of $50 \%$ formalin and $50 \% 1 \mathrm{M} \mathrm{H}_{3} \mathrm{PO}_{4}$. ETS activity was corrected to in situ temperature when necessary using the Arrhenius equation with an activation energy of $15 \mathrm{kcal} \mathrm{mol}^{-1}$ (Owens \& King 1975).

Measurement of oxygen uptake. Oxygen uptake was determined following Cammen (1985) incubating the animals in custom-made plexiglass chambers $(10 \mathrm{~cm}$ high, $7 \mathrm{~cm}$ diameter) with a teflon stirrer suspended from the lid; slow stirring was maintained throughout the incubations. Dissolved oxygen concentration was measured using an Endeco Type 1125 Pulsed D.O. System with 4 Endeco Type 1128 D.O. Probes; the probes were inserted through the lids of the chambers. The procedure was to establish an initial uptake rate over several hours of measurement prior to the addition of the animals; the uptake rate of the animals was monitored until it had stabilized and then measured for at least $1 \mathrm{~h}$. The water used in the chambers was collected along with the animals and filtered through a $0.2 \mu \mathrm{m}$ filter. For the starvation measurements, the animals were either left free in the chambers with no sediment, or allowed to settle into appropriate lengths and diameters of U-shaped Tygon tubing. They were acclimated for 1 to $5 \mathrm{~d}$ to the experimental temperature.

Conversions among measures of body weight. Individual Nereis virens and groups of 5 to 120 similar- 
sized Corophium volutator, including the full range of body sizes used for the ETS and oxygen measurements, were analyzed for organic carbon and nitrogen content using a Control Equipment Model 240-XA CHN analyzer. These results were used to scale the metabolic measurements to nitrogen content since the organic matter:wet weight ratio was quite different for the 2 species. The relationship among wet weight (WW), dry weight (DW) and organic nitrogen (N) for the 2 species was determined as follows (all weights in $\mathrm{mg}$, logs are base 10):

$$
\begin{array}{rlrl}
N \text { virens: } & \log \mathrm{DW} & =-0.713+0.975 \log \mathrm{WW} \\
(\mathrm{n}=10) & \left(\mathrm{r}^{2}\right. & =0.99) \\
& \log \mathrm{N} & =-1.743+1.006 \log \mathrm{WW} \\
\left(\mathrm{r}^{2}\right. & =0.99) \\
\text { C. volutator: } & \log \mathrm{DW} & =-0.591+1.022 \log \mathrm{WW} \\
(\mathrm{n}=6) & \left(\mathrm{r}^{2}\right. & =0.99) \\
& & \log \mathrm{N} & =-1.627+0.950 \log \mathrm{WW} \\
\left(\mathrm{r}^{2}\right. & =0.99)
\end{array}
$$

Relation between body size and ETS activity. A range of body sizes of Nereis virens and Corophium volutator were collected from the field, frozen immediately, and assayed to determine the relationship of ETS activity with body size. Twelve individual $N$. virens were used for the assay; the $C$. volutator were divided into 6 size-classes containing from 5 to 60 individuals. Log-log regressions were calculated relating ETS activity to dry weight and to organic nitrogen.

Measurement of R:ETS ratio. In order to make the measurements of oxygen uptake as realistic as possible, we made the measurements with the animals in natural sediment. They were collected from the field in March and April and placed natural sediment for $1 \mathrm{~d}$ to allow acclimation to the $10^{\circ} \mathrm{C}$ experimental temperature. About 1 to $1.5 \mathrm{~cm}$ of gently homogenated surface sediment (top $0.5 \mathrm{~cm}$ ) was then placed into each of the chambers (the sediment was not sieved, but visible macrofauna were removed), oxygen uptake of the sediment alone was measured, either 1 Nereis virens (average individual dry weight $50.5 \mathrm{mg}$ ) or 5 to 10 Corophium volutator (average individual dry weight $2.2 \mathrm{mg}$ ) were added, and after the animals had been given $1 \mathrm{~h}$ to settle into the sediment, the oxygen measurements were repeated; oxygen uptake of the animals was calculated by subtraction. Following those measurements the animals were assayed for ETS activity.

Effect of starvation on oxygen uptake and ETS activity. We carried out 3 starvation experiments where animals were maintained without food for 10 to $12 \mathrm{~d}$ and both oxygen uptake and ETS activity were followed throughout. In the first 2 experiments, the animals were collected in late May and maintained at $10^{\circ} \mathrm{C}$ in the absence of sediment and food. Nereis virens were kept individually in $50 \mathrm{ml}$ centrifuge tubes and the Corophium volutator were kept together in a large tray; oxygen uptake measurements were carried out with the animals free in the experimental chambers. For the third experiment, $N$. virens were collected in September and maintained at $20^{\circ} \mathrm{C}$ in plastic tubes, simulating natural burrows (Kristensen 1981); the tubes and worms were transferred directly to the chambers for the oxygen uptake measurements.

\section{RESULTS}

\section{Assay conditions}

The first task of this project was to establish the optimal assay conditions for the ETS assay; among the factors investigated were $\mathrm{pH}$, substrate species and concentrations, assay length, and storage of the homogenates prior to the assay. We found that the assay parameters used by Owens \& King (1975) for zooplankton $(\mathrm{pH}$ of $8.5,1.0 \mathrm{mM} \mathrm{NADH}$ and $0.15 \mathrm{mM}$ NADPH as substrates) were also suitable for use with macrofaunal organisms.

Storage of the homogenates prior to the incubations appeared to affect the ETS assay. There was an initial increase in corrected optical density (COD) of the assays as storage time increased followed by a decrease; the time-course of the response was accelerated as temperature increased (Fig. 1). The pattern of the response was fairly similar for both species: At $10^{\circ} \mathrm{C}$, peak COD was observed after $4 \mathrm{~h}$ with an increase over the initial reading of $59 \%$ for Nereis virens and $51 \%$ for Corophium volutator. At $20^{\circ} \mathrm{C}$, COD declined after $4 \mathrm{~h}$ to $44 \%$ of the peak value for $N$ virens and to $45 \%$ of the peak value for $C$. volutator. For the purposes of this study, we took a conservative approach and did not store the homogenates; incubations were carried out immediately following the homogenization of the animals (see 'Discussion')

\section{Measurement of R:ETS ratio}

The calculated ratios for animals in natural sediment were $0.09 \pm 0.02(\mathrm{SE}, \mathrm{n}=4$ ) for Nereis virens and 0.42 $\pm 0.05(\mathrm{n}=4)$ for Corophium volutator these ratios may be compared to the mean of 0.49 for zooplankton summarized by Packard (1985b).

\section{Effect of starvation on oxygen uptake and ETS activity}

The general trend of each of these experiments was that oxygen uptake declined over time, but ETS activ- 

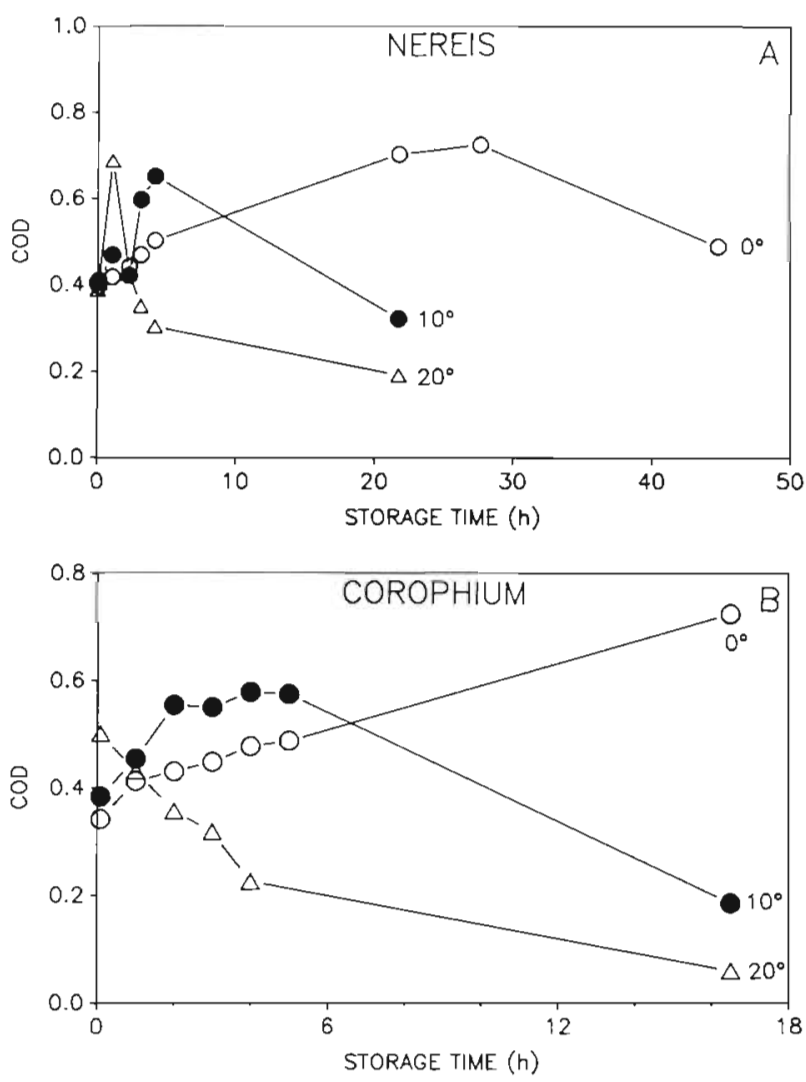

Fig. 1. Response of the ETS assay (as corrected optical density, COD) for (A) Nereis virens and (B) Corophium volutator after storing the homogenate for various times prior to assay at 0 , 10 , and $20^{\circ} \mathrm{C}$

ity showed little variation (Fig. 2). The result was a gradual decline in the R:ETS ratio during the 10 to $12 \mathrm{~d}$ of the experiments. The R:ETS ratios for the Nereis virens experiments were similar despite the fact that the animals were free in the chambers during the $10^{\circ} \mathrm{C}$ experiment and settled into plastic tubes for the $20^{\circ} \mathrm{C}$ experiment. The lower R:ETS ratios for starving animals compared to those measured in natural sediment were due to the reduced rate of oxygen uptake, not a shift in the level of ETS activity. The oxygen uptake rates for Corophium volutator on Day 3 were anomalously high, but since we could not identify any obvious problems with the measurements, the data have been included; the difference between Day 2 and Day 3 was significant for oxygen uptake $(p<0.02)$, but not for the R:ETS ratio.

\section{Relation between body size and ETS activity}

A series of assays carried out on the 2 experimental species showed that ETS activity was related to body size in a manner typical for a metabolic function (Table 1 ): ETS $=\alpha W^{\beta}$; the exponents were significantly
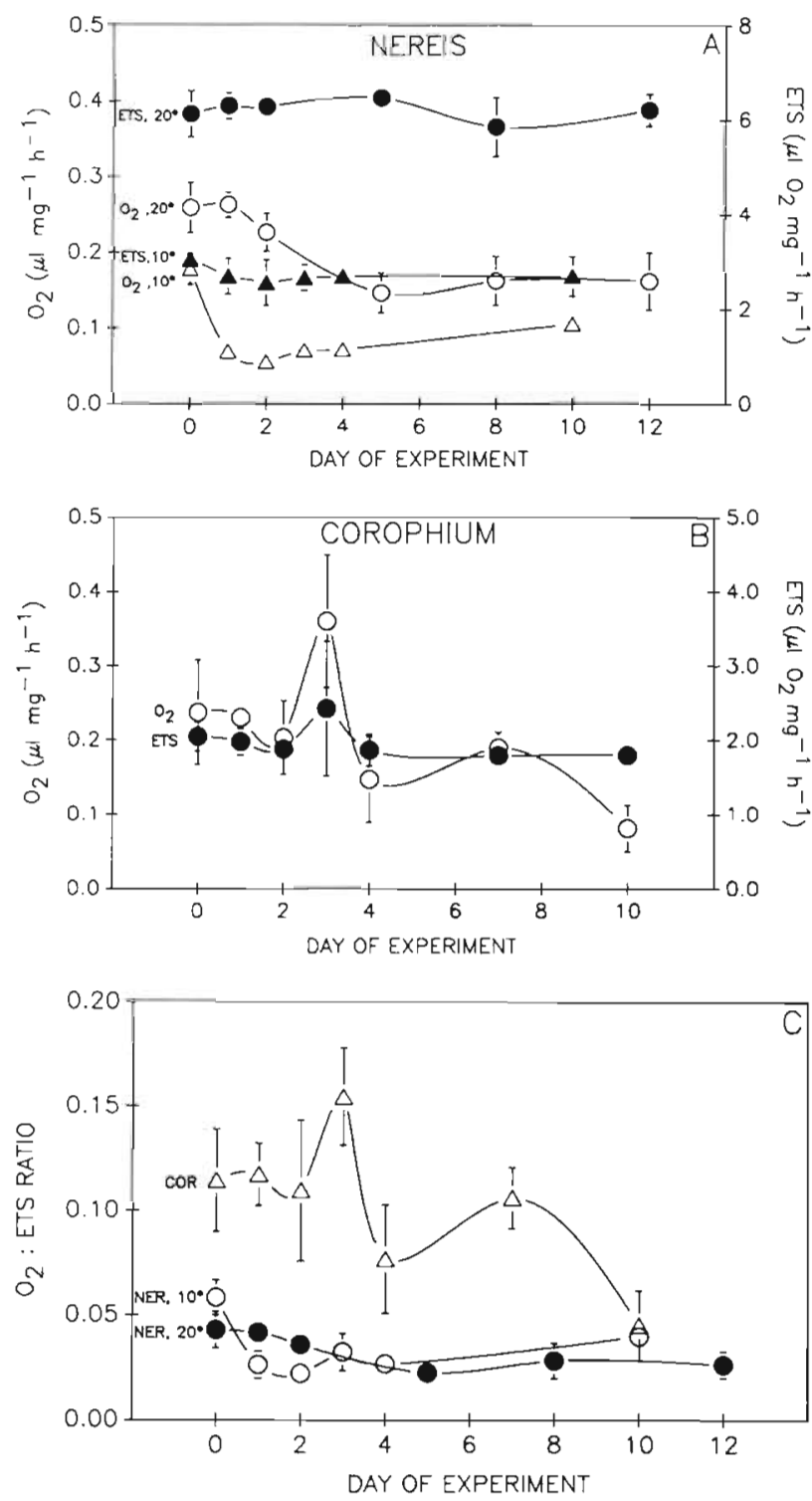

Fig. 2. Oxygen uptake and ETS activity during starvation as a function of wet body weight; rates were scaled to a hypothetical $1 \mathrm{mg}$ animal using the values of $\beta$ from Table 1. (A) Nereis virens, separate experiments were run at $20^{\circ} \mathrm{C}$ with worms in tubes and at $10^{\circ} \mathrm{C}$ with worms free in the chambers; (B) Corophium volutatur, a single experiment at $10^{\circ} \mathrm{C}_{i}$ (C) R:ETS ratios during the 3 experiments. Error bars represent $95 \%$ confidence limits

different from 1 indicating that ETS is not simply a conservative measure of body mass. The variation in the exponents for dry weight and organic $N$ was due to the fact that the percent organic $\mathrm{N}$ varies with body size.

\section{Seasonal variation in ETS activity}

Assays carried out on a series of animals collected between March and October and frozen immediately in liquid nitrogen showed that there was a seasonal 
Table 1. Nereis virens and Corophium volutator. Relationship between ETS activity and body size in terms of wet weight, dry weight and organic nitrogen. The fitted equation was $\log$ ETS $=\log \alpha+\beta \log W$ where ETS was $\mu l O_{2} h^{-1}$ and $W$ was mg wet weight, dry weight or organic nitrogen; all values of $\mathrm{r}^{2}$ were greater than 0.98 . Standard errors of the estimates are given in parentheses

\begin{tabular}{|rcc|} 
& Corophium & Nereis \\
\hline Wet weight & & \\
$\log \alpha$ & $0.33(0.04)$ & $0.39(0.05)$ \\
$\beta$ & $0.88(0.06)$ & $0.82(0.02)$ \\
Dry weight & & \\
$\log \alpha$ & $0.84(0.03)$ & $0.99(0.04)$ \\
$\beta$ & $0.86(0.06)$ & $0.84(0.02)$ \\
Organic N & & \\
$\log \alpha$ & $-0.94(0.11)$ & $-0.63(0.08)$ \\
$\beta$ & $0.92(0.06)$ & $0.81(0.02)$ \\
\hline
\end{tabular}

response to ETS activity for both experimental species (Fig. 3). In order to emphasize the response to factors other than temperature, these rates have not been corrected to in situ temperature, but instead represent the enzymatic activity at a common temperature of $10^{\circ} \mathrm{C}$. There was a marked difference between the 2 species when rates were expressed on a dry weight basis, but the difference disappeared during most of the year if activity was expressed in terms of body nitrogen content; however, the seasonal pattern of ETS activity was quite different for the 2 species. Corophium volutator ETS activity was lower in early spring and consistently higher from early summer through fall. Nereis virens, on the other hand, had its highest activity in the early spring and a lower but consistent level of activity in the summer and fall.

\section{DISCUSSION}

It appears that ETS activity may be useful as an estimator of long-term, integrated metabolic activity in marine macrofauna. Smith \& Chong (1982) pointed out several requirements with respect to time scale that a parameter must satisfy if it is to serve as a metabolic indicator including: (1) there must be no acute adaptation on the scale of sample collection and processing; (2) it must, however, retain the potential to acclimate eventually to changes in the overall level of metabolism; and (3) it should have an allometric relationship with body mass similar to that for metabolism. ETS activity appears to meet each of the requirements in the 2 species included in this study as discussed below

The first condition that must be met if the ETS method is to be useful in studies of macroinfaunal energetics is that the ETS activity of the animals must
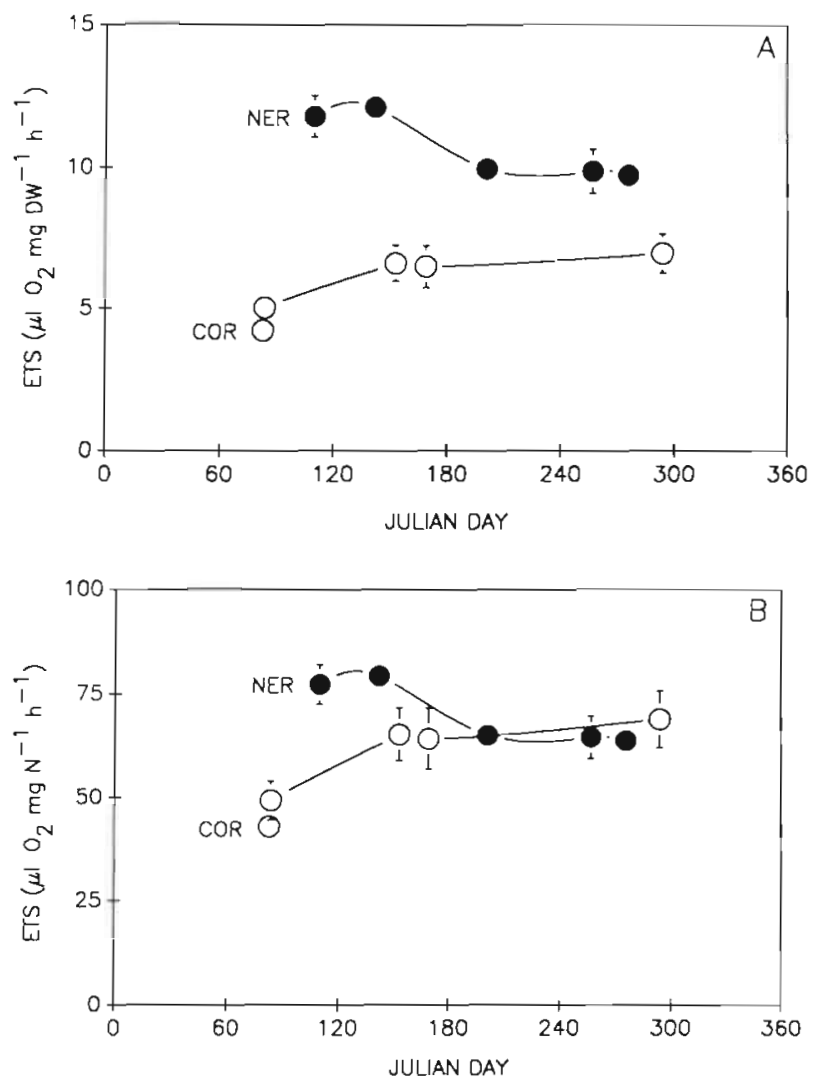

Fig. 3. Seasonal pattern in ETS activity for Nereis virens (NER) and Corophium volutator (COR) as a function of (A) dry body weight, and (B) organic nitrogen content; rates were scaled to a hypothetical $1 \mathrm{mg}$ animal using the values of $\beta$ from Table 1. Error bars represent $95 \%$ confidence limits

not change significantly during the time it takes to remove them from the sediment and stabilize the activity by transferring them to liquid nitrogen. On a theoretical basis, the response of the ETS, which involves the synthesis and degradation of macroenzymes, should be slower than the response in respiration rate. Finlay et al. (1983) found just such a pattern in their experiments with Protozoa where the time required to synthesize macromolecular cell components is relatively long (>75 min) while the time required to initiate catabolism of a new substrate in a starving individual is relatively short $(<10 \mathrm{~min})$; the result was that when a starving cell was exposed to food, the initial increase in respiration rate was limited by the amount of ETS 'machinery' available and further increases were delayed until the synthesis of the appropriate ETS macromolecular components. As Bămstadt (1980) and Smith \& Chong (1982) have pointed out, because ETS activity does not adapt acutely to short-term variations in environmental factors (such as sample collection and stabilization), the method has a major advantage over direct respiratory measurements on animals in the laboratory. The results of the starvation experiments 
reported here show, for example, that while oxygen uptake was significantly altered during starvation, ETS activity was much more stable and continued to reflect the condition of the animals at the time starvation was initiated.

The second condition for usefulness of the assay was that there should eventually be acclimation to changes in the overall level of metabolism. Although ETS activity in Nereis virens and Corophium volutator remained relatively stable during the starvation experiments, both species did show variable ETS activity on a seasonal basis. However, it was not possible from this limited study to determine conclusively which factors in the environment might have been responsible for the observed changes in ETS activity. First considering the most obvious environmental variable, temperature, all assays were carried out at $10^{\circ} \mathrm{C}$, not at the in situ temperature of the organisms. There were 2 reasons for this experimental design: First, we wanted to emphasize factors contributing to variability in ETS activity other than temperature; and second, given the highly fluctuating diurnal temperature regime of an intertidal mudflat in this area (greater than $20^{\circ} \mathrm{C}$ during summer), it was not at all clear how best to determine the appropriate assay temperature. Therefore, the possibility exists that some of the variation in ETS activity we observed during the course of this study was due to incomplete metabolic compensation to seasonal temperature changes by the experimental animals. There are several strategies that could result in such variability in apparent enzyme activity on a seasonal time scale (Hochachka \& Somero 1984) including changing the concentration of pre-existing enzymes, modulating the activities of pre-existing enzymes, and changing the types of enzymes present in the organism; any or all of these modes of action may have been involved in the apparent adaptation we observed. However, only the former possibility would necessarily be detected with the constant assay temperature used in this study.

A second potentially important factor in explaining the seasonal variation in ETS activity is the nutritional status of the animals. Corophium volutator is a selective, surface deposit feeder whose major source of nutrition is microalgae and bacteria (Hawkins 1985). In the mudflat used for this study, microbial biomass is minimal in early spring and increases fairly steadily until mid-fall (Cammen unpubl.); the ETS results for $C$. volutator are thus consistent with the suggestion that a minimal biomass of its major food resource results in reduced metabolic activity. Nereis virens, on the other hand, is a non-selective deposit feeder and occasional carnivore; based on knowledge of other nereids and deposit feeders, much of the organic matter it assimilates is probably in the form of organic detritus
(Cammen 1980, 1989). Bacterial production in this mudflat is low during the winter, rises rapidly until April, and then declines (Cammen unpubl.) indicating the presence of a pool of relatively available organic material accumulated throughout the late fall and winter. This organic matter would have been available to $N$. virens in the spring at the same time its $\mathrm{N}$-specific ETS activity was maximal; later in the year, when the pool of available organic matter would have declined, $N$. virens ETS activity was also lower.

A third factor with the potential to account for some of the variability in apparent ETS activity is the presence of reproductive activity for the 2 species. Corophium volutator populations show reproductive activity beginning in April and extending until October (Fish \& Mills 1979); this pattern correlates well with the observed ETS activity. Nereis virens reproduces in early spring (Pettibone 1963, Creaser \& Clifford 1982) which again correlates with elevated ETS activity. Since this study included only adults for most of the sampling periods, it was not possible to determine whether reproductive activity itself was a primary factor responsible for elevating ETS activity or just a secondary response to other factors affecting ETS activity; this could be determined by sampling the entire age-distribution (including non-reproducing juveniles) seasonally.

The third requirement for the ETS assay to serve as a useful metabolic indicator is that it must show an allometric relationship with body mass. There was just such a relationship for both species on both a dry weight and on organic $\mathrm{N}$ basis. For purposes of comparison among species it appears that organic $\mathrm{N}$ may be a better parameter to use for scaling the ETS activity measurements since $\mathrm{N}$ is more closely related to organic matter and hence to metabolically active tissue than total dry weight (Zeuthen 1947). A recent study of ETS activity in meiobenthic nematodes and copepods (Houri-Davignon et al. 1989) reported that ETS activity was directly proportional to body mass (measured as protein), but recalculation of the data given in the paper do not necessarily support that conclusion. Using the complete set of nematode data, the exponent $B$ of the power function relating ETS activity to protein content was 1.01 (GM regression; $r=0.69, \mathrm{n}=11$ ); however, with the removal of one outlying data point, the power function exponent became 0.83 ( $\mathrm{r}=0.71$, $\mathrm{n}=10, \mathrm{p}<0.03)$. Recalculation of the complete set of copepod data gave a power function exponent of 0.84 ( $r=0.80, n=11, p<0.02$ ). The problem is that the range of body sizes was too limited in that study to make it possible to distinguish a linear model from a power function. The reanalysis of the data shows that the relationship found in that study between ETS and body mass was similar to that found in this study. 
The effect of storage of the homogenate prior to the ETS assay was reviewed recently by Schalk (1988) and the literature is contradictory. Part of the explanation may be that some of the observations in previous studies were so infrequent that an initial increase might have been overlooked if it were followed in turn by a rapid decrease. The initial increases and subsequent decreases seen in this study fit closely a model consisting of an exponential increase to an asymptote which in turn is decreasing exponentially to $0\left(r^{2}=0.94\right.$ to 0.99$)$, but other formulations might have fit equally well. In the time allotted to this project, we were unable to determine the actual mechanism behind this response and are unsure if it represents an artifact resulting from storage of the homogenate or a real release of additional enzymes. Therefore, we chose a conservative approach and used the initial assay results determined immediately following preparation of the homogenates. Schalk (1988) concludes by recommending that only whole organisms be stored, not homogenates, and we concur.

Since we cannot measure in situ respiration directly for most macroinfauna, it will be necessary to use an R:ETS ratio that has been determined in the laboratory. There have been a series of zooplankton studies designed to determine the effects of holding animals in the laboratory on the R:ETS ratio (Båmstedt 1980, Ikeda \& Skjoldal 1980, Skjoldal et al. 1984). ETS activity and respiration decreased during the holding period in each of these studies, but after a few days the R:ETS ratios were essentially the same as those found immediately after capture, regardless of whether the animals were fed or starved. The animals were collected as gently as possible and the authors argued on the basis of supporting physiological and biochemical experiments that the initial high values of respiration were not due to capture stress, but instead were representative of the natural level of metabolic activity for the zooplankton; the decrease in metabolic activity during holding was attributed mainly to food shortage. Thus, there was an inherent and relatively robust relationship between respiration and ETS activity for those zooplankton. This suggests that if macroinfauna were held for a sufficient time in the laboratory, their R:ETS ratios should approximate those found in situ; however, as shown above, the holding time might need to be much longer than for the zooplankton. For macrofauna, it would seem to be preferable to measure the R:ETS ratio as soon as possible in the laboratory, mimicking as closely as possible the natural conditions so as to achieve the greatest accuracy in the measurement of oxygen uptake. Although it would be desirable to avoid the necessity for laboratory measurements to determine the appropriate conversion factors, it will be some time before we have enough experience to predict suitable factors without working in the laboratory.
The method used here to measure oxygen uptake by animals in the presence of sediment potentially overestimated their respiration rates. Since oxygen uptake of the animals was calculated as the increase in oxygen uptake of the chambers following the addition of the animals, it was necessary to assume that sediment oxygen uptake was not affected by the presence of the animals. This assumption may have been violated to some extent since animals probably affect sediment microbial activity through grazing and bioturbation. It is difficult to evaluate the degree of error introduced to the measurements since most experimental investigations into the subject have been concerned with longterm effects of animals upon sedimentary microbes; however, such evidence suggests that the effects may be minor (Alongi 1985). A series of studies by Findlay and co-workers on short-term effects of disturbance on sedimentary microbes in a variety of systems showed that the effects on biomass and activity varied in magnitude and even direction (Findlay et al. 1985, 1990a, b); that is, in some of the experiments over the first few hours, specific activity or growth increased, but total biomass decreased. It is also possible bioturbation might have increased chemical oxidation of reduced products of anaerobic respiration in the sediment within the chambers. However, since the sediment was collected from the upper $0.5 \mathrm{~cm}$ of the mudflat, it is unlikely that anaerobic respiration was important. The background sediment oxygen uptake in the respiration chambers accounted for an average of $49 \%$ of the final combined animal and sediment oxygen uptake. When we consider that the animals are affecting only a fraction of the total sediment in the chambers, it seems reasonable to conclude that whatever the error that might be inherent in this experimental design, the approach is preferable to the alternative of carrying out the measurements in the absence of sediment.

A final caveat with applying the ETS method to benthic infauna arises because many of those organisms derive a portion of their energy from anaerobic metabolic pathways. Intertidal organisms, in particular, can experience periods of anoxia which may cause them to switch over to anaerobic metabolism (Scott 1976, de Zwaan 1977, Schöttler 1979, Hammen 1980. Hochachka 1980, Pamatmat 1983, Schöttler et al. 1984, Cammen 1987, Kristensen 1989). This change does not occur abruptly, but instead is a gradual transition from a predominantly aerobic to a predominantly anaerobic mode (Warren 1981, Schöttler et al. 1983). Upon return to aerobic conditions, the accumulated metabolic end products are either reoxidized (payment of the 'oxygen debt'), used to resynthesize glycogen (gluconeogenesis), or simply excreted into the water Since metabolic rate generally decreases during periods of anaerobiosis (Hochachka \& Somero 1984), estimates 
based solely on aerobic measurements will overestimate the total metabolic rate. This problem is inherent with using oxygen uptake to estimate total metabolism for facultative anaerobes, but the use of ETS activity does not eliminate the problem. The extent of the error depends upon the relative difference between the aerobic and anaerobic metabolic rates and the fraction of time the animals respire anaerobically (Pamatmat 1983); unfortunately, there have been few determinations of anaerobic metabolic rates (Hochachka et al. 1973, Gnaiger 1983, Pamatmat 1983, Shick et al. 1983), and we usually still do not know the fraction of time the animals respire anaerobically. Laboratory measurements are unlikely to be instructive in this regard, due to the difficulty in simulating the magnitude and extent of the field conditions which contribute to the onset of anerobiosis. Some tissues of active organisms such as Nereis spp. probably function anaerobically during rapid body movement despite the presence of adequate levels of oxygen in the environment (Schötler 1979). $N$. virens experiences anoxic conditions within minutes following ventilation periods in burrows both with and without sediment and begins to respire anaerobically (Scott 1976, Kristensen 1989), showing that not only is anaerobic metabolism important during low tide (Schöttler et al. 1984), but that it undoubtedly occurs routinely even when the burrows are submerged; thus, even though the starvation experiments in this study were carried out in the absence of sediment and with constant aeration, the $N$. virens probably were alternating periods of aerobic and anaerobic metabolism. Since aspects of the ETS continue to function during anaerobic metabolism (Hochachka et al. 1973), ETS activity as determined with this assay will tend to integrate anaerobic and aerobic metabolism. For species that undergo prolonged and variable periods of anaerobiosis, however, the ETS assay may not give a reliable estimate of metabolic rate.

The decline in oxygen uptake by Nereis virens and Corophium volutator during starvation observed in this study was predictable (Newell 1979), but the relative stability of the ETS activity may differ from results of previous studies of smaller organisms, The $44 \%$ decrease in the rate of oxygen uptake by $N$. virens after $5 \mathrm{~d}$ of starvation was similar to the $50 \%$ decrease observed for the same species after $6 \mathrm{~d}$ in a previous study (Kristensen 1989). Kristensen cites several studies of other marine invertebrates that show a general pattern of a 40 to $60 \%$ reduction in oxygen uptake rate during the initial 4 to $8 \mathrm{~d}$ of starvation followed by a period where the uptake rate remains constant. Previous researchers have found ETS activity per individual to decline during starvation in protozoa (Finlay et al. 1983) and zooplankton (Båmstedt 1980, Skjodal et al. 1984) with time scales ranging from hours for the pro- tozoa to tens of hours for the zooplankton. However, when the protozoan data were expressed on a volumespecific basis, there was only a slight decrease in ETS activity; no concurrent weight data were given for the zooplankton studies, but since other studies of starvation in zooplankton have shown weight losses ranging from 0.4 to $15 \% \mathrm{~d}^{-1}$ (Alvarez \& Matthews 1975, Båmstedt \& Holt 1978, Lemcke \& Lampert 1975 as cited in Båmstedt \& Holt 1978), it seems likely that at least some of the reported decrease in ETS activity per individual was actually due to loss of body mass during the incubations. The organisms in this study showed little change in $\mathrm{N}$-specific ETS activity during 10 to $12 \mathrm{~d}$ of starvation, but, for example, if the rate of weight loss during starvation for $N$. virens had been typical of that reported elsewhere for nereid polychaetes, namely 0.3 to $4.3 \%$ (Kay \& Brafield 1973, Tenore \& Gopalan 1974 , Neuhoff 1979), ETS activity per individual on Day 12 of the experiments could have been as low as $59 \%$ of the level on Day 0. However, given the comparatively large size of the animals used in this study, it would not be surprising if they were able to maintain their complement of ETS 'machinery' for a longer period of time than either protozoa or zooplankton; for example, the response in the maximum rate of oxygen consumption. by man (analagous to the 'potential' measured by ETS activity) to increased exercise training was evident only after 3 wk (Henriksson \& Reitman 1977). There would be an obvious advantage to buffering the response of the ETS since that would allow the animals to resume maximal respiration immediately upon return to more favorable conditions without the necessity of waiting for the synthesis of suitable macromolecular cellular components.

Although the R:ETS ratio of Corophium volutator in natural sediment was similar to those found previously for zooplankton, the comparatively low R:ETS ratio of Nereis virens was unanticipated. Based on the relationship between weight and R:ETS ratio from King \& Packard (1975), a $50.5 \mathrm{mg}$ dry weight $N$. virens would have a predicted R:ETS ratio of 0.39 , compared to the measured value of 0.09 ; the R:ETS ratio predicted for a $2.2 \mathrm{mg}$ dry weight $C$. volutator would be 0.45 , compared to the measured value of 0.42 . To be sure the oxygen uptake measured for $N$. virens in this study was not unusually low, we compared the uptake measured here (136 $\mu \mathrm{g} \mathrm{O}_{2} \mathrm{~g}^{-1} \mathrm{~h}^{-1}$ ) to that found by Kristensen (1981) in a previous study of ventilation and oxygen uptake for Nereis spp.; taking his value at $16^{\circ} \mathrm{C}$ and converting to $10^{\circ} \mathrm{C}$ using Krogh's normal curve gives a similar uptake rate of $131 \mu \mathrm{g} \mathrm{O}_{2} \mathrm{~g}^{-1} \mathrm{~h}^{-1}$. The implication, then, is that $N$. virens metabolic processes differ in some basic manner from those of $C$. volutator and the zooplankton. A recent study of meiobenthos ETS activity also reported relatively low R:ETS ratios of 0.10 to 
0.63 (mean 0.24) for nematodes and 0.09 to 0.31 (mean 0.18 ) for copepods (Houri-Davignon et al. 1989), but because oxygen uptake was measured with the animals removed from the sediment, the ratios cannot be considered to represent natural values.

There are several important differences among Nereis virens, Corophium volutator and zooplankton other than just the obvious taxonomic distinction, namely adult body size and mode of life. Adult $N$. virens are much larger than the other taxa, live a more sedentary lifestyle, and are intermittently exposed to anoxic conditions. C. volutator are somewhat intermediate in this comparison in terms of body size and activity and would not be as likely to experience anoxia. Zooplankton in general would be smaller, more active and would probably never experience anoxia. Evidence from other work on R: ETS ratios suggest that body size may explain some of the difference since larger organisms tend to have ratios somewhat lower (King \& Packard 1975), but as shown above, that effect is not large enough to account for the entire variation among the groups. Shumway (1979) has shown that polychaetes can be grouped successfully as to their oxygen consumption according to their general level of activity. In theory, though, whether the animals are sedentary or active should not affect the R:ETS ratio since both oxygen uptake and ETS activity should adjust with time to reflect the level of activity; there are several studies showing that they do in fact covary (e.g. Bamstedt 1980). However, even though the overall activity level of $N$. virens is relatively low compared to C. volutator or zooplankton, the animals still need to maintain the capacity for periods of elevated metabolic activity (Mangum \& Burnett 1975, Kristensen 1989); the result would be a higher metabolic scope than for more consistently active species. In addition, the presence of anaerobic metabolism in $N$. virens, even during oxic conditions, may entail additional demands upon the ETS that would be independent of oxygen uptake (see discussion above). It is apparent that before we can generalize about suitable conversion factors for other benthic invertebrates, we will first need to gain a better understanding of the factors controlling the ratio between ETS activity and oxygen uptake

\section{SUMMARY}

The major conclusion from this study is that ETS activity has the potential to identify seasonally important factors independent of temperature that determine metabolic rates in macrobenthos. It is apparent that there will be a range of factors relating respiration rate to ETS activity, but it is not yet clear how much those factors will depend on body size, taxa or life-style.
Since the response time of ETS activity in adult macrobenthos appears to be on the order of weeks, the technique lends itself to studies of integrated responses to environmental factors over that time frame; in particular, the problems of stress responses to capture or acclimatization to laboratory conditions are avoided. However, before the technique can be applied routinely in benthic ecology, it will first be necessary to determine the relationship between respiration and ETS activity for a variety of other macrobenthos. Those additional data will show whether generalized R:ETS ratios will be suitable for either taxonomic or ecological species groups, or whether it will be necessary to determine an appropriate ratio for each individual species.

Acknowledgements. Support for this study was provided by NSF grant No. OCE-8711393.

\section{LITERATURE CITED}

Ahmed, S. 1, Kenner, R. A., King, F. D. (1976). Preservation of enzyme activity by low temperature freezing. Mar. Chem 4: $133-139$

Alongi, D. M. (1985). Effect of physical disturbance on population dynamics and trophic interactions among microbes and meiofauna. J. mar. Res. 43: 351-364

Alvarez, V., Matthews, J. B. L. (1975). Experimental studies on the deep-water pelagic community of Korsfjorden, western Norway: feeding and assimilation by Chiridius armatus (Crustacea, Copepoda). Sarsia 58: 67-78

Båmstedt, U. (1980). ETS activity as an estimator of respiratory rate of zooplankton populations. The significance of variations in environmental factors. J. exp. mar Biol. Ecol. 42: $267-283$

Bảmstedt, U., Holt, M. R. (1978). Experimental studies on the deep-water pelagic community of Korsfjorden, western Norway: prey-size preference and feeding of Euchaeta norvegica (Copepoda). Sarsia 64: 225-236

Bayne, B. L., Bayne, C. J., Carefoot, T C., Thompson, R. J. (1976). The physiological ecology of Mytilus californianus Conrad. 1. Metabolism and energy balance. Oecologia (Berl.) 22: 211-228

Cammen, L. M. (1980). The significance of microbial carbon in the nutrition of the deposit feeding polychaete Nereis succinea. Mar. Biol. 61: 9-20

Cammen, L. M. (1985). Metabolic loss of organic carbon by the polychaete Capitella capitata (Fabricius) estimated from initial weight decrease during starvation, oxygen uptake. and release of ${ }^{14} \mathrm{C}$ by uniformly-labeled animals. Mar. Ecol. Prog. Ser. 21: 163-167

Cammen, L. M. (1987). Polychaetes In: Pandian, T J., Vernberg, F. J. (eds.) Animal energetics. Academic Press, New York, p. 217-260

Cammen, L. M. (1989). The relationship between ingestion rate of deposit feeders and sediment nutritional value. In: Lopez, G., Taghon, G., Levinton, J. (eds.) Ecology of marine deposit feeders. Lecture Notes on Coastal and Estuarine Studies, Springer-Verlag, New York, p. 201-222

Christensen, J. P., Packard, T. T. (1979). Respiratory electron transport activities in phytoplankton and bacteria: comparison of methods. Limnol. Oceanogr 24. 576-583 
Conover, R. J. (1978). Transformation of organic matter In: Kinne, O. (ed.) Marine ecology, Vol. IV, Dynamics. John Wiley and Sons, Chichester, p. 221-499

Creaser, E. P., Clifford, D. A. (1982). Life history studies of the sandworm, Nereis virens Sars, in the Sheepscot Estuary, Maine. Fish. Bull. U.S. 80: 735-743

Cuzon, G., Cahu, C., Aldrin, J. F., Messenger, J. L., Stephan, G., Mevel, M. (1980). Starvation effect on metabolism on Penaeus japonicus. Proc. World Maricult. Soc. 11: 410-423

Famme, P., Kofoed, L. H. (1982). Rates of carbon release and oxygen uptake by the mussel Mytilus edulis L. in response to starvation and oxygen. Mar Biol. Lett. 3: 241-256

Findlay, R. H., Pollard, P. C., Moriarty, D. J. W., White, D. C. (1985). Quantitative determination of microbial activity and community nutritional status in estuarine sediments: evidence for a disturbance artifact. Can. J. Microbiol. 31: 493-498

Findlay, R. H., Trexler, M. B., White, D. C. (1990a). Response of a benthic microbial community to biotic disturbance. Mar. Ecol. Prog. Ser. 62: 135-148

Findlay, R. H., Trexler, M. B., Guckert, J. B., White, D. C. (1990b). Laboratory study of disturbance in marine sediments: response of a microbial community. Mar. Ecol. Prog. Ser. 62: 121-133

Finlay, B. J., Span, A., Ochsenbein-Gattlen, C. (1983). Influence of physiological state on indices of respiration rate in protozoa. Comp. Biochem. Physiol. 74A: 211-219

Fish. J. D., Mills, A. (1979). The reproductive biology of Corophium volutator and C. arenarium (Crustacea: Amphipoda) J. mar biol. Ass. U.K. 59: 355-368

Gnaiger, E. (1983). Heat dissipation and energetıc efficiency in animal anoxibiosis: Economy contra power. J. exp. Zool. 228: $471-490$

Hammen, C. S. (1980). Total energy metabolism of marine bivalve mollusks in anaerobic and aerobic states. Comp. Biochem. Physiol. 67 A: 617-621

Hand, S. C. Somero, G. N. (1983). Energy metabolism pathways of hydrothermal vent animals: adaptations to a foodrich and sulfide-rich deep-sea environment. Biol. Bull. mar. biol. Lab., Woods Hole 165: 167-181

Hargrave, B. T (1971). An energy budget for a depositfeeding amphipod. Limnol. Oceanogr. 16: 99-103.

Hawkins, C. M. (1985). Population carbon budgets and the importance of the amphipod Corophium volutator in the carbon transfer on a Cumberland Basin mudflat, upper Bay of Fundy, Canada. Neth. J. Sea Res. 19: 165-176

Henriksson, J., Reitman, J. S. (1977). Time course of changes in human skeletal muscle succinate dehydrogenase and cytochrome oxidase activities and maximal oxygen uptake with physical activity and inactivity. Acta Physiol. Scand. 99: $91-97$

Hochachka, P. W. (1980). Living without oxygen. Closed and open systems in hypoxia tolerance. Harvard University Press, Cambridge

Hochachka, P. W., Fields, J., Mustafa, T (1973). Animal life without oxygen: basic biochemical mechanisms. Am. Zool 13: $543-555$

Hochachka, P. W., Somero, G. N. (1984). Biochemical adaptation. Princeton Univ. Press, Princeton

Houri-Davignon, C., Relaxans, J. C., Castel, J. (1989). Oxygen consumption and Electron-Transport-System (ETS) activity of meiobenthic nematodes and copepods: methodology, size-dependence, contribution to total benthic metabolism. Océanis 15: 499-510

Ikeda, T., Skjoldal, H. R. (1980). The effect of laboratory conditions on the extrapolation of experimental measurements to the ecology of marine zooplankton. VI. Changes in physiological activities and biochemical components of Acetes sibogae australis and Acartia australis after capture. Mar Biol. 58: 285-293

Kay, D. G., Brafield, A. E. (1973). The energy relations of the polychaete Neanthes ( $=$ Nereis) virens (Sars). J. Anim. Ecol. 42: 673-692

King, F. D., Packard, T. T. (1975). Respiration and the respiratory electron transport in marine zooplankton. Limnol. Oceanogr 20: 849-854

Kofoed, L. H. (1975). The feeding biology of Hydrobia ventrosa (Montagu). II. Allocation of the components of the carbon-budget and the significance of the secretion of dissolved organic material. J. exp. mar. Biol. Ecol. 19: 243-256

Kristensen, E. (1981). Direct measurement of ventilation and oxygen uptake in three species of tubiculous polychaetes (Nereis spp.). J. comp. Physiol. 145: 45-50

Kristensen, E. (1989). Oxygen and carbon dioxide exchange in the polychaete Nereis virens: influence of ventilation activity and starvation. Mar. Biol. 101: 381-388

Lane, J. M., Lawrence, J. M. (1979). The effect of size, temperature, oxygen level, and nutritional condition on oxygen uptake in the sand dollar, Mellita quinquiesperforata (Leske). Biol. Bull. mar. biol. Lab., Woods Hole 157 $275-287$

Lemcke, H. W., Lampert, W. (1975). Veränderungen im Gewicht und der chemischen Zusammensetzung von Daphnia pulex im Hunger Arch. Hydrobiol. 48 I (Suppl.): $108-137$

Mangum, C. P., Burnett, L. E. (1975). The extraction of oxygen by estuarine invertebrates. In: Vernberg, F. J. (ed.) Physiological ecology of estuarine organisms. Univ. South Carolina Press, Columbia, p. 147-163

Mangum, C. P., Miyamoto, D. M. (1970). The relation between spontaneous activity cycles and diurnal rhythms of metabolism in the polychaetous annelid Glycera dibranchiata. Mar. Biol. 7:7-10

Mangum, C. P., Sassaman, C. (1969). Temperature sensitivity of active and resting metabolism in a polychaetous annelid. Comp. Biochem. Physiol 30: 111-117

Neuhoff, H.-G. (1979). Influence of temperature and salinity on food conversion and growth of different Nereis species (Polychaeta, Annelida). Mar. Ecol. Prog. Ser. 1: 255-262

Newell, R. C. (1979). Biology of intertidal animals. Marine Ecological Surveys Ltd., Faversham

Nichols, F. H. (1975). Dynamics and energetics of three deposit-feeding benthic invertebrate populations in Puget Sound, Washington. Ecol. Monogr 45: 57-82

Owens, R. G., King, F. D. (1975). The measurement of respiratory electron-transport system activity in marine zooplankton. Mar. Biol. 30: 27-36

Packard, T T. (1985a). Oxygen consumption in the ocean: Measuring and mapping with enzyme analysis: In: Zirino. A. (ed.) Advances in chemistry series 209. American Chemical Society, Washington, D.C., p. 178-209

Packard, T T. (1985b). Measurement of electron transport activity of microplankton. In: Williams, P. J. leB., Jannasch, H. (eds.) Advances in aquatic microbiology, Vol. 3. Academic Press, New York, p. 207-261

Pamatmat, M. M. (1982). Metabolism of a burrowing polychaete: precaution needed when measuring toxic effects. Mar. Pollut. Bull. 13: 364-367

Pamatmat, M. M. (1983). Measuring aerobic and anaerobic metabolism of benthic infauna under natural conditions. J. exp. Zool. 228: 405-413

Pamatmat, M. M., Findlay, S. (1983). Metabolism of microbes, nematodes, polychaetes, and their interactions in sedi- 
ment, as detected by heat flow measurements. Mar Ecol. Prog. Ser. 11 31-38

Parsons, T. R., Takahashi, M., Hargrave, B. (1984). Biological oceanographic processes, 3rd edn. Pergamon Press, New York

Pettibone, M. H. (1963). Marine polychaete worms of the New England region. 1. Aphroditidae through Trochochaetidae. U. S. natn. Mus. Bull. 227: 1-356

Sander, F. (1973). A comparative study of respiration in two tropical marine polychaetes. Comp. Biochem. Physiol. 46A: $311-323$

Schalk, P. H. (1988). Respiratory electron transport system (ETS) activities in zooplankton and micronekton of the Indo-Pacific region. Mar Ecol. Prog. Ser. 44: 25-35

Schottler, U. (1979). On the anaerobic metabolism of three species of Nereis (Annelida). Mar. Ecol. Prog. Ser. 1: $249-254$

Schöttler, U., Wienhausen, G., Zebe, E. (1983). The mode of energy production in the lugworm Arenicola marina at different oxygen concentrations. J. comp. Physiol. 149: $547-555$

Schöttler, U., Surholt, B., Zebe, E. (1984). Anaerobic metabolism in Arenicola marina and Nereis diversicolor during low tide. Mar. Biol. 81: 69-73

Scott, D. M. (1976). Circadian rhythm of anaerobiosis in a polychaete annelid. Nature, Lond. 262: 811-813

Shick, J. M., de Zwaan, A., de Bont, A. M. Th. (1983), Anoxic metabolic rate in the mussel Mytilus edulis L. estimated by simultaneous direct calorimetry and biochemical analysis. Physiol. Zool. 56: 56-63

Shumway, S. E. (1979). The effects of body size, oxygen tension and mode of life on the oxygen uptake rates of polychaetes. Comp. Biochem. Physiol. 64A: 273-278

This article was presented by Professor K. R. Tenore, Solomons, Maryland, USA
Skjoldal, H. R., Båmstedt, U., KJinken, J., Laing, A. (1984) Changes with time after capture in the metabolic activity of the carnivorous copepod Euchaeta norvegica Boeck. J. exp. mar Biol. Ecol. 83: 195-210

Smith, J. C., Chong, C. K. (1982). Body weight, activities of cytochrome oxidase and electron transport system in the liver of the American plaice Hippoglossoides platessoides. Can these activities serve as indicators of metabolism? Mar. Ecol. Prog. Ser. 9: 171-179

Tenore, K. R., Gopalan, U. K. (1974). Feeding efficiencies of the polychaete Nereis virens cultured on hard-clam tissue and oyster detritus. J. Fish, Res. Bd Can. 31: 1675-1678

Vernberg, F. J. (1959). Studies on the physiological variation between tropical and temperate zone fiddler crabs of the genus $U_{\mathrm{Ca}} \mathrm{II}$. Oxygen consumption of whole organisms. Biol. Bull. mar. biol. Lab., Woods Hole 117: 163-184

Vernberg, W. B., Coull, B. C., Jorgensen, D. D. (1977). Reliability of laboratory measurements of meiofauna. J. Fish Res. Bd Can. 34: 164-167

Vosjan, J. H. (1982). Respiratory electron transport system activities in marine environments. Hydrobiol Bull. 16: 61-68

Wallace, J. C. (1973). Feeding, starvation and metabolic rate in the shore crab Carcinus maenas. Mar. Biol. 20: 277-281

Warren, L. M. (1981). Respiratory adaptations to temporary hypoxia by the polychaete Cirriformia tentaculata. Comp. Biochem. Physiol. 69A: 321-324

Zaba, B. N. (1983). On the nature of oxygen uptake in two tissues of Mytilus edulis. Mar Biol. Lett. 4: 59-66

de Zwaan, A. (1977). Anaerobic energy metabolism in bivalve molluscs. Oceanogr. mar. Biol. A. Rev. 1.5:103-187

Zeuthen, E. (1947). Body size and metabolic rate in the animal kingdom with special regard to the marine micro-fauna. $C$ R. Trav. Lab. Carlsberg, Ser. Chim. 26: 17-161

Manuscript first received: July 20,1989

Revised version accepted: May 15, 1990 